\title{
Chapter 13 \\ Timing Potassium Applications to Synchronize with Plant Demand
}

\author{
V. K. Singh, B. S. Dwivedi, S. S. Rathore, R. P. Mishra, T. Satyanarayana, \\ and K. Majumdar
}

\begin{abstract}
Potassium (K) demand by crops is almost as high as that of nitrogen (N) and plays a crucial role in many plant metabolic processes. Insufficient $\mathrm{K}$ application results in soil $\mathrm{K}$ mining, deficiency symptoms in crops, and decreased crop yields and quality. Crop $\mathrm{K}$ demands vary with crop types, growth patterns, nutrient needs at different physiological stages, and productivity. Science-based K application in crops needs to follow 4R Nutrient Stewardship to ensure high yield, improved farm income, and optimum nutrient use efficiency. Studies around the world report widespread $\mathrm{K}$ deficiency, ranging from tropical to temperate environments. Long-term experiments indicate significant yield responses to $\mathrm{K}$ application and negative $\mathrm{K}$ balances where $\mathrm{K}$ application is either omitted or applied suboptimally. Limited understanding of $\mathrm{K}$ supplementation dynamics from soil non-exchangeable $\mathrm{K}$ pools to the exchangeable and solution phases and overreliance on native $\mathrm{K}$ supply to meet crop demand are major reasons for deficit of $\mathrm{K}$ supply to crops. Research on optimum timing of $\mathrm{K}$ fertilizer application in diverse climate-soil-crop systems is scarce. The common one-time basal $\mathrm{K}$ management
\end{abstract}

V. K. Singh $(\bowtie) \cdot$ S. S. Rathore

Division of Agronomy, ICAR-Indian Agricultural Research Institute, New Delhi, India

B. S. Dwivedi

Division of Soil Science and Agricultural Chemistry, ICAR-Indian Agricultural Research Institute, New Delhi, India

e-mail: head_ssac@iari.res.in

R. P. Mishra

ICAR-Indian Institute of Farming Systems Reserach, Meerut, Uttar Pradesh, India

T. Satyanarayana

Division of Agronomy and Advisory Services, K Plus S Middle East FZE, Dubai, UAE

$\mathrm{K}+\mathrm{S}$ Minerals and Agriculture GmbH, Kassel, Germany

e-mail: Satya.Talatam@k-plus-s.com

K. Majumdar

African Plant Nutrition Institute and Mohammed VI Polytechnic University, Ben Guerir, Morocco

e-mail: k.majumdar@apni.net

(C) The Author(s) 2021

T. S. Murrell et al. (eds.), Improving Potassium Recommendations for Agricultural

Crops, https://doi.org/10.1007/978-3-030-59197-7_13 
practice is often not suitable to supply adequate $\mathrm{K}$ to the crops during peak demand phases. Besides, changes in crop establishment practices, residue retention, or fertigation require new research in terms of rate, time, or source of $\mathrm{K}$ application. The current review assesses the synchrony of K supply from indigenous soil system and from external sources vis-à-vis plant demand under different crops and cropping systems for achieving high yield and nutrient use efficiency.

\subsection{Introduction}

Potassium $(\mathrm{K})$ is required by plants in large quantities, equal to or more than nitrogen $(\mathrm{N})$, and plays a key role in many metabolic processes. The arable lands are deficient in K globally, which include three-fourth of the paddy soils of China and two-third of the wheat belt of Southern Australia. Additionally, the export of agricultural products and leaching of K, particularly in sandy soils, contribute to the lowering of soil K content (Rengel and Damon 2008). Soils on which K deficiency occurs vary widely, and include acid sandy soils, waterlogged soils, and saline soils (Mengel and Kirkby 2001). Globally, the annual above-ground parts of crops (phytomass) contain 75,14 , and 60 million tons of $\mathrm{N}, \mathrm{P}$, and $\mathrm{K}$, respectively, which are being utilized for other purposes (e.g., heating, animal feed, biofuels). In India, animal dung (as fuel cakes) and crop residues are used as a source of bioenergy for cooking and heating without recycling the K-rich ash or sludge back to farming land that receives only low, if any, input of $\mathrm{K}$ fertilizers (Hasan 2002). Globally, $\mathrm{K}$ is applied at a much lower level to replenish only $35 \%$ of the K removed by crops (Smil 1999). Hence widespread $\mathrm{K}$ deficiency is observed in major production regions of the world. Potassium-deficient plants, besides producing low yields, become susceptible to drought, excess water, high and low temperatures, and to pests, diseases, and nematodes. Soil K availability is largely governed by soil mineralogical composition. Extent and pathways of weathering of primary K-bearing minerals and the dynamic equilibrium between soil $\mathrm{K}$ fractions give rise to soils of varying K-supplying capacity. Most soils of great alluvial flood plains in Asia were considered to have high $\mathrm{K}$ fertility due to the abundant presence of K-rich clay minerals (Dobermann et al. 1998; De Datta and Mikkelsen 1985), and K was rarely found a limiting factor in crop production (Bajwa 1994). Later studies, however, indicated continuous soil $\mathrm{K}$ depletion due to higher $\mathrm{K}$ withdrawal than its supplement (Dobermann et al. 1998; Bijay-Singh et al. 2003; Yadvinder-Singh et al. 2005; Singh et al. 2013, 2014).

Recent studies conducted in intensively cultivated areas of India showed imbalanced $\mathrm{N}$ use, optimal to suboptimal $\mathrm{P}$ use, and complete neglect of $\mathrm{K}$ application by the farmers (Dwivedi et al. 2001; Singh et al. 2014, 2015a; Syers 2003). Timsina et al. (2013) associated soil $\mathrm{K}$ fertility depletion with high nutrient demand and excessive extraction of $\mathrm{K}$ in intensive production systems of Asia. Such depletion was further aggravated by the general practice of removing crop residues from the field for other competitive uses. This has led to widespread K deficiency in many 
soils, including the fine-textured soils that originally had high soil $\mathrm{K}$ contents. The examples include alluvial illitic soils of India (Singh et al. 2015b), lowland rice soils of Java (Sri Adiningsih et al. 1991), and vermiculitic clay soils of Central Luzon, Philippines (Dobermann and Oberthür 1997). Evidence from long-term experiments in different cropping systems in India and elsewhere showed significant yield responses to $\mathrm{K}$ application, and negative $\mathrm{K}$ balances where $\mathrm{K}$ application is either omitted or applied suboptimally (Dwivedi et al. 2017). Depletion of soil K has been considered as a possible cause of yield decline of rice and wheat in the long-term rice-wheat systems (RWS) of Indo-Gangetic Plains (IGP) of South Asia (Ladha et al. 2003; Regmi et al. 2002). The K content in crops depends on soil type, crop, and fertilizer input; however, concentrations in the range of $0.4-4.3 \%$ have been reported (Askegaard et al. 2004). Öborn et al. (2005) concluded in a literature survey that crop $\mathrm{K}$ concentrations are often well below $(<2.5-3.5 \%)$ what is needed to avoid deficiency. For many crops, the critical $\mathrm{K}$ concentration is in the range $0.5-2 \%$ in dry matter (Leigh and Wyn Jones 1984).

Potassium demand of crops varies with crop type, growth pattern, nutrient needs at different physiological stages, and crop productivity. High $\mathrm{K}$ demand of crops is associated with its high extraction from soils, which may lead to declining $\mathrm{K}$ fertility unless the extracted $\mathrm{K}$ is replenished through external sources. The use efficiency of applied K varies with cropping systems (Singh et al. 2014, 2015b), soil indigenous supplying capacity, source, rate, time, and method of $\mathrm{K}$ application. These factors, along with the variable $\mathrm{K}$ availability in soils, needs to be considered while formulating $\mathrm{K}$ management strategies in cropping systems. The current review assesses the synchrony of $\mathrm{K}$ supply through soil and external sources vis-à-vis plant demand. Aspects considered include soil characteristics, indigenous K supply, residue management, crop growth behavior, uptake pattern, and the importance of synchronizing soil K supply and plant need for sustainable high crop productivity and farm income.

\subsection{Why the Emphasis on Potassium?}

Improving nutrient use efficiency is a global concern. However, among the primary nutrients, $\mathrm{K}$ often gets less attention compared with $\mathrm{N}$ and P. Fixen et al. (2015) reported that world partial factor productivity (PFP) for K increased between 1983 and 2007, approaching $145 \mathrm{~kg}$ production $\mathrm{kg}^{-1} \mathrm{~K}$ (Fig. 13.1). In general, PFP for K tended to increase in Africa, North America, Europe, and EU15, whereas a downward trend was observed in Latin America, India, and China. These researchers also synthesized global ranges for partial factor productivity (PFP), agronomic efficiency (AE), and recovery efficiency (RE) of K for rice-wheat systems, and reported PFP of $\mathrm{K}$ varying from 75 to $200 \mathrm{~kg} \mathrm{~kg}^{-1} \mathrm{~K}$. Similarly, $\mathrm{AE}$ and $\mathrm{RE}$ varied from 8 to $20 \mathrm{~kg}$ $\mathrm{kg}^{-1} \mathrm{~K}$ and $30-50 \%$, respectively.

The average RE of $\mathrm{K}$ in on-farm trials conducted before 1998 as summarized by Dobermann (2007) that fell in the range of 38-51\%. In China, the ranges of RE and AE (Jin 2012) observed in field trials between 2002 and 2006 were 25-32\% and 


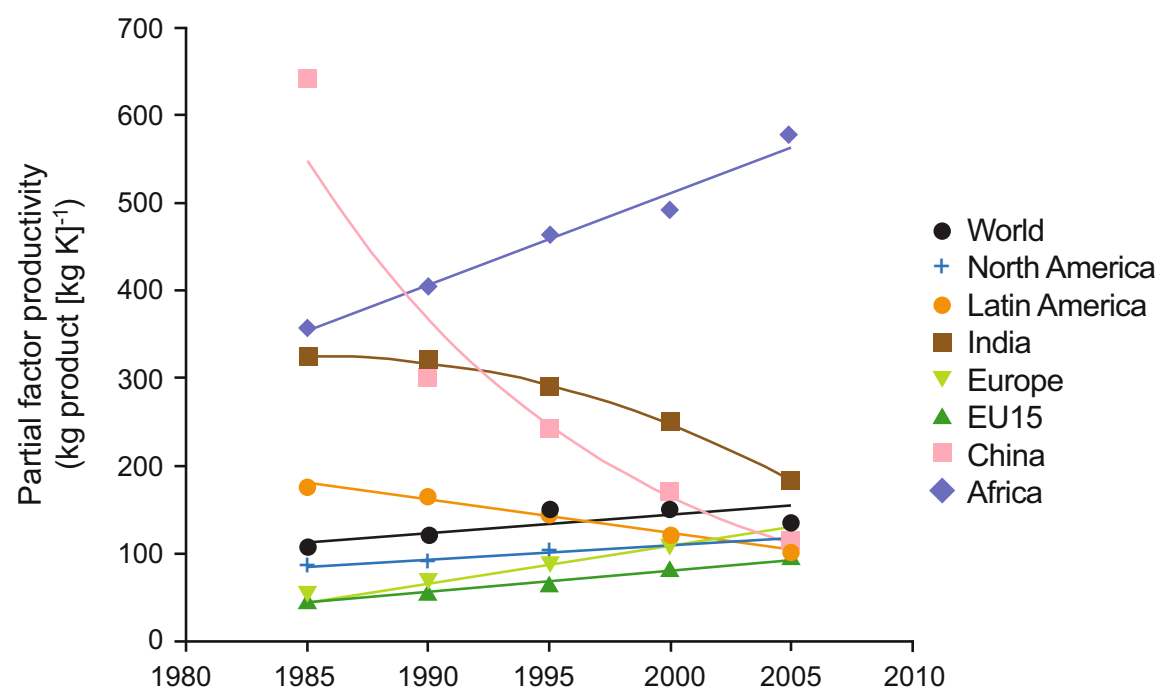

Fig. 13.1 Partial factor productivity of K in different global regions during 1983-2007. (Fixen et al. 2015)

8-12 $\mathrm{kg} \mathrm{kg}^{-1} \mathrm{~K}$ for cereal crops. The RE was relatively higher (34-44\%) for field trials on winter wheat in Northcentral China, while the AE values were in the range of $8-10 \mathrm{~kg} \mathrm{~kg}^{-1} \mathrm{~K}$ (He et al. 2012). The researchers observed that the $\mathrm{K}$ application rates probably exceeded the optimum for the soil $\mathrm{K}$ supply of individual site-year that led to lower AE values. Dobermann (2007) suggested that AE levels of $10-20 \mathrm{~kg} \mathrm{~kg}^{-1} \mathrm{~K}$ were realistic targets for cereals on soils that do not have high available $\mathrm{K}$ reserves.

In the Indian context, the need for enhancing nutrient use efficiency is felt more than ever before for at least two reasons: (i) increasing production of food grains and other crops will require more nutrients, whereas there is less likelihood of significant increase in fertilizer consumptions in foreseeable future due to economic and environmental constraints; and (ii) research established inefficient fertilizer use as one of the most important causes of soil health deterioration and lowering farm income (Tiwari 2002; Tiwari et al. 2006; Dwivedi and Meena 2015). Enhancing K use efficiency (KUE) is of particular significance, as India meets its entire K requirement through imports. Besides, the substantial increase in the retail price of $\mathrm{K}$ fertilizers, consequent to the implementation of nutrient-based subsidy since 2010, necessitates judicious use of $\mathrm{K}$ fertilizers and calls for enhancement in its use efficiency which seldom exceeds $60 \%$ KUE.

Plants acquire $\mathrm{K}$ from the soil solution as $\mathrm{K}^{+}$ions. Depending on soil type, 90-98\% of soil $\mathrm{K}$ is relatively unavailable. The K-bearing minerals (especially feldspar and mica) are the source of soil $\mathrm{K}$, which release $\mathrm{K}$ very slowly to the more available forms. Readily available $\mathrm{K}$ is composed of soil solution $\mathrm{K}$ and exchangeable $\mathrm{K}$. In general, solution $\mathrm{K}$ ranges from 1 to $2 \%$ and exchangeable $\mathrm{K}$ 
from 1 to $10 \%$. An equilibrium exists between non-exchangeable, exchangeable, and soil solution $\mathrm{K}$. Because of this equilibrium, some of the soluble $\mathrm{K}$ applied as fertilizer gets temporarily converted to the non-exchangeable $\mathrm{K}$, thus decreasing KUE.

\subsection{The Need to Synchronize Potassium Supply with Plant Demand}

In most annual crops, basal application of the full dose of $\mathrm{K}$ fertilizer is a common practice, though it may lead to low KUE as K demand of crops varies with crop growth pattern, nutrient needs at different physiological stages, and productivity level. For instance, both rice and wheat require large quantities of $\mathrm{K}$, and a sustained supply is necessary until the heading or reproductive stage is over. In fact, most of the applied $\mathrm{K}$ before/at the time of sowing got exhausted from the soil through its further transformations to other K pools, resulting in its lower availability during the crop reproductive phase. Thus, an unsynchronized K supply often affects economic yield adversely.

Potassium is highly mobile in plants and differences between genotypes in the efficiency of $\mathrm{K}$ utilization have been attributed to differences in their capacity to translocate $\mathrm{K}$ at a cellular and whole plant level (Fig. 13.2). Under K deficiency, cytosolic K activity is maintained at the expense of vacuolar K activity (Leigh 2001, Memon et al. 1985), even though vacuolar (but not cytosolic) $\mathrm{K}$ activity is regulated differently in the root and leaf cells (Cuin et al. 2003). The capacity to translocate $\mathrm{K}$ between organs may also be an important mechanism for efficient $\mathrm{K}$ utilization within the plant (Dunlop and Tomkins 1976).

Potassium is not a constituent of any of the cell organelle, but it has a substantial regulatory role in the growth and development of plants. Since K is involved in $>60$

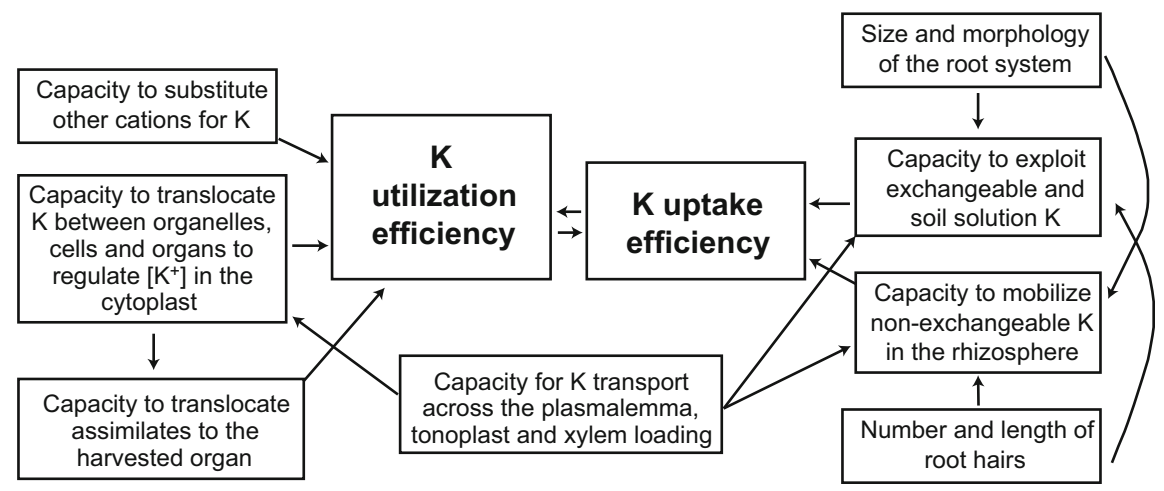

Fig. 13.2 Potential mechanisms of $K$ uptake and utilization efficiency and their interactions that influence the expression of the K-efficient phenotype. (Pettigrew 2008) 
enzymatic systems in plants, often referred to as the "the regulator." Potassium helps crop plants in the synthesis of carbohydrates, regulates the opening and closing of stomata and affects root growth which is required for efficient water use. The $\mathrm{K}$ stimulates active sites of enzymes for reaction. The $\mathrm{K}$ amount in the cell determines activation and rates of chemical reaction of enzymes. Therefore, the rate of a given enzymatic reaction is regulated by $\mathrm{K}$ entering the cell. When $\mathrm{K}$ moves into the guard cells around the stomata, the cells accumulate water and swell, causing the pores to open and allowing smooth gas exchange. When the water supply is short, $\mathrm{K}$ is pumped out of the guard cells. Under water stress, stomata close tightly to prevent excessive loss of water. Accretion of $\mathrm{K}$ in plant roots produces a gradient of osmotic pressure that draws water into the roots. Plants deficient in $\mathrm{K}$ are thus less able to absorb water and are more prone to stress when water is scarce.

Potassium involvement in ATP production and activation of enzymes is undoubtedly more significant in regulating the rate of photosynthesis than is the role of $\mathrm{K}$ in stomatal activity. The loading of photosynthates in sink is regulated by $\mathrm{K}$. The plant transport system uses energy in the form of ATP. If $\mathrm{K}$ is inadequate, less ATP is available, and the transport system breaks down. This causes photosynthates to build up in the leaves, and the rate of photosynthesis is reduced. As a result, the normal development of energy storage organs, such as grain, is impeded. An adequate K supply helps to keep all of these processes and transportation systems functioning normally. Translocation of nitrate, phosphate, calcium $(\mathrm{Ca})$, magnesium $(\mathrm{Mg})$, and amino acids is decreased under short supply of $\mathrm{K}$. During the reproductive stages of crop plants, $\mathrm{K}$ and $\mathrm{Mg}$ in source leaves play a critical role by ensuring an adequate supply of sucrose and $\mathrm{K}, \mathrm{Mg}, \mathrm{N}, \mathrm{P}$, and $\mathrm{S}$ to the grain filling, fruits, and tubers (Kirkby and Römheld 2004). The enzyme nitrate reductase catalyzes the formation of proteins, and $\mathrm{K}$ is likely responsible for its activation and synthesis. When plants are deficient in $\mathrm{K}$, proteins are not synthesized despite an abundance of available $\mathrm{N}$. The importance of high harvest index as a mechanism of K utilization efficiency has been widely documented for a number of species, including wheat (Damon et al. 2007, Woodend and Glass 1993, Zhang et al. 1999). Even short periods of K deficiency, especially during critical developmental stages, can cause serious losses. Potassium improves the physical quality, disease resistance, and shelf life of fruits and vegetables and the feeding value of grain and forage crops, and fiber quality of cotton. Quality can also be affected in the field before harvesting such as when $\mathrm{K}$ reduces lodging. Thus, $\mathrm{K}$ is required by the plants throughout the life cycle, and the synchronized supply of $\mathrm{K}$ with demand ensures not only high productivity but also the quality of the produce.

The critical $\mathrm{K}$ demand stages of some of the important crops are given in Table 13.1.

Multi-locational studies conducted under cereal-based systems in IGP indicated that high $\mathrm{K}$ demand of crops is associated with its high extraction from soils, which may lead to declining $\mathrm{K}$ fertility unless replenished through external sources (Dwivedi et al. 2017; Singh et al. 2014, 2018). Other factors that influence the efficiency of applied $\mathrm{K}$ in the crops are the cropping system followed, indigenous $\mathrm{K}$ supplying capacity of soil, and source, rate, time, and method of $\mathrm{K}$ application. 
Table 13.1 Critical potassium demand stages in different crops

\begin{tabular}{l|l}
\hline Crop $^{\text {a }}$ & Critical potassium demand crop stages \\
\hline Rice & Initial growth (15-45 days after transplanting) and panicle emergence \\
\hline Wheat & Initial crop growth (30 days after sowing), tillering, and reproductive stage \\
\hline Maize & $\begin{array}{l}\text { Initial crop growth (VE to V3), knee-high (V5 to V7) stage, and reproductive stage } \\
\text { (tasseling, silking, and cob formation) }\end{array}$ \\
\hline Cotton & Boll formation and fiber formation \\
\hline Sugarcane & $\begin{array}{l}\text { Grand growth phase (45-90 days after sowing) and sugar formation stage (120-170 } \\
\text { days after sowing) }\end{array}$ \\
\hline
\end{tabular}

${ }^{\mathrm{a} C o t t o n}$ (Gossypium hirsutum L.); maize (Zea mays L.); rice (Oryza sativa L.); sugarcane (Saccharum giganteum (Walter) Pers.); wheat (Triticum aestivum L.)

\subsection{Managing Potassium to Synchronize Supply with Plant Demand}

Soil K remains in four pools, which differ in availability to crop plants. These are soil solution $\mathrm{K}$, exchangeable $\mathrm{K}$, non-exchangeable $\mathrm{K}$ (positioned in interlayers of clay minerals, especially those of the 2:1 type), and structural K (Moody and Bell 2006; Majumdar and Sanyal 2015). Potassium that is dissolved in soil water (watersoluble) plus that held on the exchange sites on clay particles (exchangeable $\mathrm{K}$ ) is considered readily available for plant use. The soluble and exchangeable $\mathrm{K}$ are the forms of $\mathrm{K}$ measured by the routine soil testing procedure. Plants absorb $\mathrm{K}$ from the soil solution pool exclusively, which is in a dynamic equilibrium with the exchangeable and, to a minor extent, the non-exchangeable pools. Soil solution plays a pivotal role in providing the pathway for $\mathrm{K}$ uptake from the soil to the plant roots. This pool is very low in $\mathrm{K}$ concentration, representing only a few percent of total crop demand at any given time (McLean and Watson 1985). In such soils, the exchangeable K pool can make a considerable contribution (80-100\%) to available $\mathrm{K}$ for plants (Hinsinger and Jaillard 2002) in some cases. Exchangeable K can be rapidly released from exchange sites on the surfaces of clay minerals and organic matter to replenish the K-depleted soil solution (Steingrobe and Claassen 2000). Non-exchangeable K can also be released into soil solution, when the soil solution $\mathrm{K}$ concentration dropped below $3.5 \mathrm{mM}$ (Springob and Richter 1998). But non-exchangeable K release from interlayer sites of clay minerals is a sluggish process and is mostly vital in contributing to the renewal of the soil solution and exchangeable pools in the long run (Pal et al. 2001a, 2002). The release of structural $\mathrm{K}$ into soil solution can be affected only by weathering of clay minerals; hence, it is a slow process with negligible effect during a single crop cycle (Pal et al. 2001b). Crop uptake synchrony is largely determined by the fate of $\mathrm{K}$ in the soil-plant system, and the $\mathrm{K}$ cycle is a powerful depiction to understand this relationship.

The rhizosphere environment has a profound effect on the native $\mathrm{K}$ supply. For example, solution $\mathrm{K}$ concentrations remain high in flooded rice soils because large amounts of soluble $\mathrm{Fe}^{2+}, \mathrm{Mn}^{2+}$, and $\mathrm{NH}_{4}{ }^{+}$ions brought into solution displace cations from the clay complex, and exchangeable $\mathrm{K}$ is released. The displacement and 
release of $\mathrm{K}$ from the exchange complex, however, ceases on return to aerobic conditions during succeeding crops like wheat, maize, etc. (Timsina et al. 2010). In fields with adequate drainage, $\mathrm{K}$ and other basic cations can be lost via leaching. The leaching losses of $\mathrm{K}$ can be substantial in highly permeable soils with low cation-exchange capacities. Yadvinder-Singh et al. (2005) found that leaching losses of K were $22 \%$ and $16 \%$ of the applied K, respectively, in sandy loam and loamy soil maintained at submerged moisture regimes. In Bangladesh, such losses were as high as $0.1-0.2 \mathrm{~kg} \mathrm{~K} \mathrm{ha}^{-1} \mathrm{day}^{-1}$ (Timsina and Connor 2001). In RWS of South Asia, a common practice is to apply the full basal dose of $\mathrm{K}$ fertilizer at the puddling of rice and at the sowing of wheat. In well-drained soils having low cation-exchange capacity, basal application of $\mathrm{K}$ to rice should be avoided. As both rice and wheat require large quantities of $\mathrm{K}$, a sustained supply is necessary through the heading stage or the reproductive stage is over. On coarse-textured soils, split application of $\mathrm{K}$ fertilizer in both rice and wheat may give higher nutrient use efficiency than its single application due to a reduction in leaching losses and luxury consumption of $\mathrm{K}$ (Tandon and Sekhon 1988). Tiwari et al. (1992) cited several references showing distinct benefits of split K applications. In Indian Punjab, Kolar and Grewal (1989) reported an average grain yield advantage of $250 \mathrm{~kg} \mathrm{ha}^{-1}$ by split application of $\mathrm{K}$ (half at transplanting + half at the tillering stage of rice), compared with a single application at transplanting.

On-farm studies conducted in RWS in the IGP indicated that the initial non-exchangeable soil $\mathrm{K}$ concentration before rice planting ranged from 1228 to $3145 \mathrm{mg} \mathrm{kg}^{-1}$ across 60 farmers' fields, and the yield gain from applied $\mathrm{K}$ was relatively constant across the range of non-exchangeable K (Fig. 13.3) (Singh et al. 2013). The relatively small difference in yield gain from applied $\mathrm{K}$ across the exchangeable soil $\mathrm{K}$ range of $60-162 \mathrm{mg} \mathrm{kg}^{-1}$ raises concerns about the effectiveness of soil testing based only on the assessment of exchangeable soil $\mathrm{K}$ to detect the probable crop response to applied K for RWS in northern India. Non-exchangeable soil $\mathrm{K}$ might be particularly important in the illite-dominated soils of the IGP, and release and plant uptake of $\mathrm{K}$ from this soil fraction might mask the $\mathrm{K}$ supplied from the exchangeable K fraction (Bijay-Singh et al. 2003).

Other studies in rice/maize systems in the IGP showed that application of $75 \mathrm{~kg}$ $\mathrm{K}_{2} \mathrm{O}$ ha $^{-1}$ to each crop in two-splits, basal and panicle emergence in rice and basal and pre-silking in maize, significantly improved $\mathrm{K}$ uptake and grain yield as compared to a single full basal application (Table 13.2).

Surface residue retention in zero-till winter maize in rice/maize systems increased $\mathrm{K}$ uptake, indicating better synchrony of $\mathrm{K}$ supply with crop demand. The increased $\mathrm{K}$ uptake by crops growing in plots with residue could be due to increased $\mathrm{K}$ input from crop residues (Table 13.3). Other authors also showed increased $\mathrm{K}$ availability in upper soil layers when residues are retained on the surface under no-till systems (Franzluebbers and Hons 1996). The surface-retained residues decompose slowly (Kushwaha et al. 2000; Balota et al. 2004) and may reduce rapid leaching of K through the soil profile, which is more likely with the incorporation of crop residue into the soil. Increased number of macropores and better aggregation in zero-till conditions increased root growth below the $15-\mathrm{cm}$ soil depth, helping $\mathrm{K}$ acquisition 
Fig. 13.3 Relationships of exchangeable $\mathrm{K}$ and non-exchangeable $\mathrm{K}$ with yield gain in rice from applied $\mathrm{K}$ across five locations in northern India

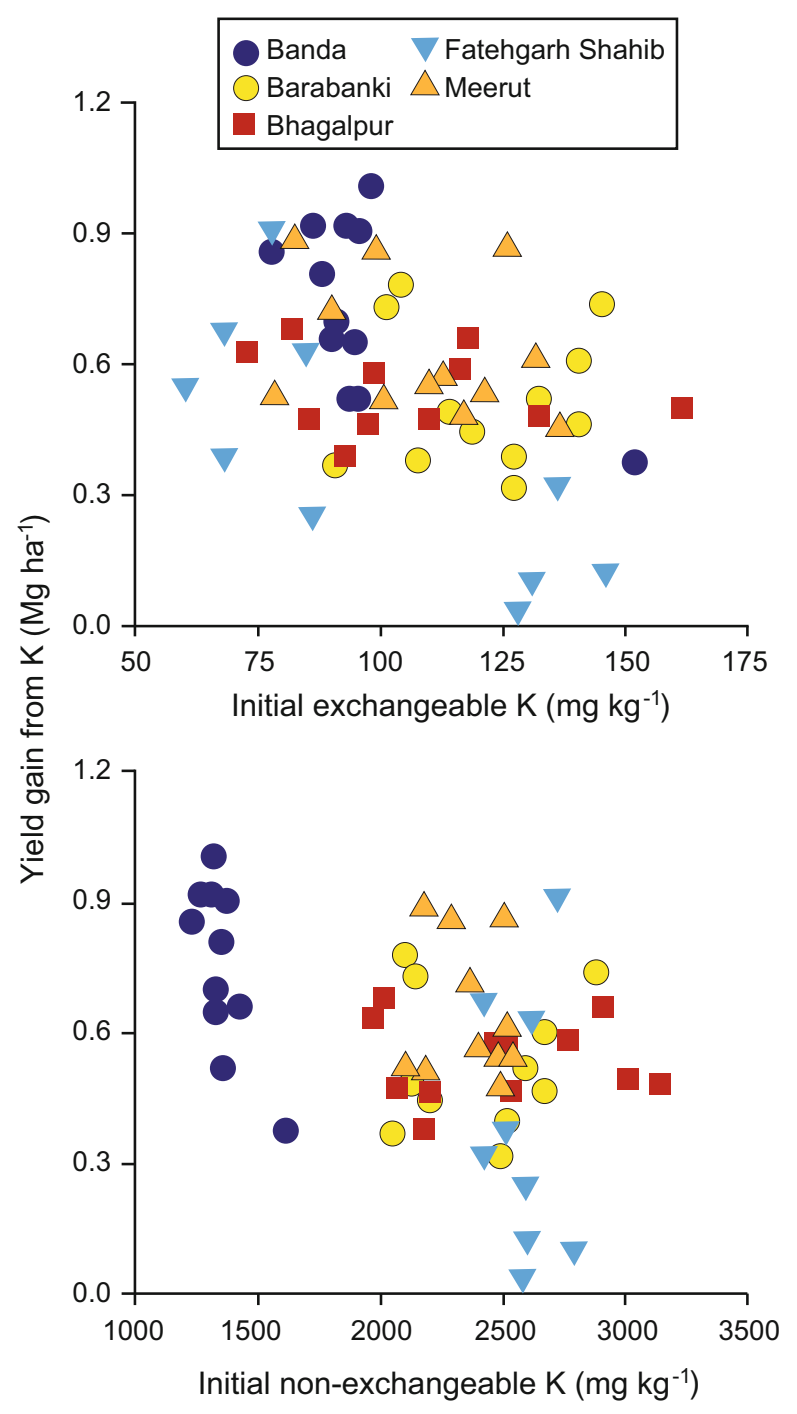

from deeper soil layers by rice and maize (Singh et al. 2018; Chakraborty et al. 2008). Surface-retained residues also reduce heat flux in and out of the soil by reflecting a large part of the solar radiation, as compared to no residues on the soil surface (Singh et al. 2018). Residues buffered soil temperature by $3.5-10^{\circ} \mathrm{C}$ during winter (early growth of maize) and by $0.8-4.8^{\circ} \mathrm{C}$ during March-April (reproductive stage of maize). An increase in soil temperature in the winter helps stimulate root and shoot growth, while a reduction in soil temperature during the grain filling stage alleviates the adverse impact of heat stress on maize productivity (Gupta et al. 2010; Wilhelm et al. 2004; Acharya et al. 1998). Researchers have observed higher moisture content in surface soil layers where crop residues are retained, increased 
Table 13.2 Effect of split $\mathrm{K}$ fertilizer application (basal and/or pre-silking) and residue retention (removed or retained) on yield, $\mathrm{K}$ agronomic efficiency $\left(\mathrm{AE}_{\mathrm{K}}\right)$, and $\mathrm{K}$ recovery efficiency $\left(\mathrm{RE}_{\mathrm{K}}\right)$ under rice-maize system

\begin{tabular}{|c|c|c|c|c|c|c|c|c|}
\hline \multirow{3}{*}{$\begin{array}{l}\mathrm{K} \text { rate } \\
\mathrm{kg} \mathrm{K}_{2} \mathrm{O} \mathrm{ha}\end{array}$} & \multirow[b]{3}{*}{ Timing } & \multirow[b]{3}{*}{ Residue } & \multicolumn{2}{|l|}{ Yield } & \multicolumn{2}{|l|}{$\mathrm{AE}_{\mathrm{K}}$} & \multicolumn{2}{|l|}{$\mathrm{RE}_{\mathrm{K}}$} \\
\hline & & & Rice & Maize & Rice & Maize & Rice & Maize \\
\hline & & & $\mathrm{Mg} \mathrm{ha}^{-1}$ & $\mathrm{Mg} \mathrm{ha}^{-1}$ & \multicolumn{2}{|c|}{ kg grain $(\mathrm{kg} \mathrm{K})^{-1}$} & \multicolumn{2}{|c|}{$\operatorname{kg~K}(\mathrm{kg} \mathrm{K})^{-1}$} \\
\hline 0 & - & - & 7.91 & 7.8 & - & - & - & - \\
\hline 75 & $\mathrm{~B}$ & rem & 8.38 & 8.4 & 7.58 & 9.68 & 0.524 & 0.502 \\
\hline 75 & $\mathrm{~B}+\mathrm{P}$ & rem & 8.69 & 8.90 & 12.58 & 17.74 & 0.608 & 0.584 \\
\hline 75 & B & ret & 8.86 & 9.37 & 15.32 & 25.32 & 0.450 & 0.411 \\
\hline 75 & $\mathrm{~B}+\mathrm{P}$ & ret & 9.10 & 9.54 & 19.19 & 28.06 & 0.533 & 0.528 \\
\hline
\end{tabular}

B, basal (at sowing); P, pre-silking (V8-V10); rem, residue removed; ret, residue retained

Table 13.3 Interactive effects of crop establishment methods and residue management on total $\mathrm{K}$ uptake in maize (5-year cumulative averages)

\begin{tabular}{l|l|l}
\hline \multirow{2}{*}{} & \multicolumn{2}{l}{$\begin{array}{l}\text { Cumulative K uptake in maize } \\
\left(\mathrm{kg} \mathrm{ha}^{\mathrm{a}}\right)\end{array}$} \\
\cline { 2 - 3 } & Residue applied $\left(\mathrm{t} \mathrm{ha}^{-1}\right)$ \\
\cline { 2 - 3 } & 0 & 4 \\
\hline Transplanted flooded rice/conventional till maize & $859 \mathrm{bB}$ & $930 \mathrm{bA}$ \\
\hline Conventional till, direct-seeded rice/conventional till maize & $921 \mathrm{bB}$ & $1018 \mathrm{aA}$ \\
\hline Zero-till, direct seeded rice/zero-till maize & $999 \mathrm{aB}$ & $1124 \mathrm{aA}$
\end{tabular}

${ }^{a}$ Within a given level of residue application, cumulative $\mathrm{K}$ uptake quantities of different cropping systems that are followed by different lowercase letters are significantly different $(p<0.05)$; within a given cropping system, cumulative $\mathrm{K}$ uptake quantities associated with the two levels of residue application that are followed by different capital letters are significantly different $(p<0.05)$

the thermal capacity of the soil, and reduced the soil temperature regime (Govaerts et al. 2009; Verhulst et al. 2010).

Potassium is required in large quantities by cotton, with peak uptake rates ranging from 3 to $5 \mathrm{~kg} \mathrm{~K} \mathrm{ha}^{-1}$ day $^{-1}$ (Halevy 1976). The developing cotton bolls are the largest $\mathrm{K}$ sink in the cotton plant (Howard et al. 1998). The K requirement dramatically increases during boll formation of cotton and, therefore, $\mathrm{K}$ application becomes crucial during the reproductive stage for higher yield (Abaye 2009). The rate of $\mathrm{K}$ uptake is slow during the seedling stage, about $10 \%$ of the total, but increases rapidly at flowering and reaches a maximum of $4.6 \mathrm{~kg} \mathrm{ha}^{-1} \mathrm{day}^{-1}$ between 72 and 84 days after planting (Halevy 1976). Mullins and Burmester (1990) reported maximum accumulation of $\mathrm{K}$ in cotton at the start of flowering, and the $\mathrm{K}$ uptake was highest during mid-bloom and then declined rapidly as the boll matured. They reported a maximum $\mathrm{K}$ uptake rate of $2.5-3.9 \mathrm{~kg} \mathrm{~K} \mathrm{ha}^{-1}$ day $^{-1}$ at flowering from 63 to 98 days after planting. During the critical period of simultaneous boll set, growth, and development, inadequate $\mathrm{K}$ uptake by the roots causes boll abortion and shedding (Pettigrew 2008). Obviously, lack of synchrony between the plant demand and soil $\mathrm{K}$ supply results in decreased fiber quality and lowered yields. In Pakistan, application of $100 \mathrm{~kg} \mathrm{~K}_{2} \mathrm{O} \mathrm{ha}{ }^{-1}$ as two equal splits, and $200 \mathrm{~kg} \mathrm{~K}_{2} \mathrm{O} \mathrm{ha}{ }^{-1}$ as four 


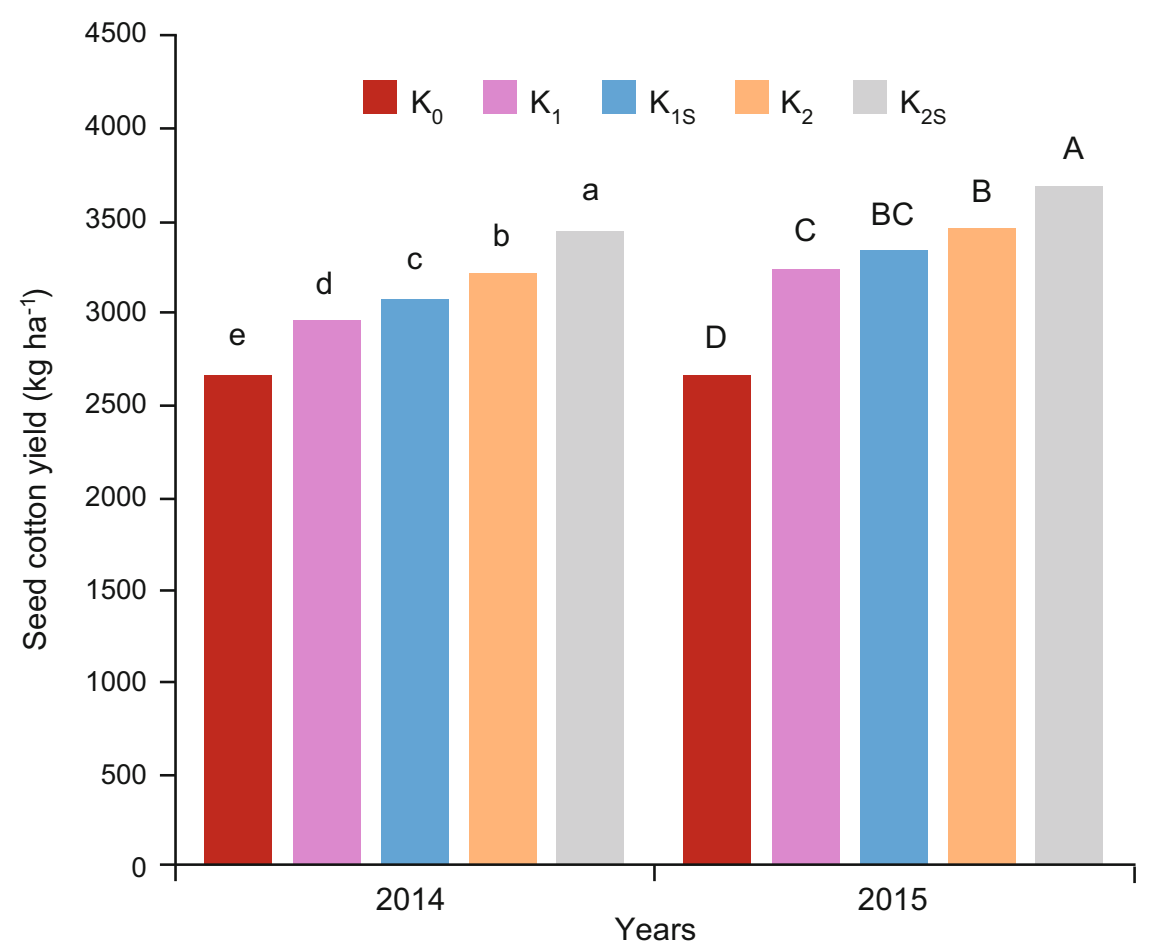

Fig. 13.4 Effect of $\mathrm{K}$ fertilization rates and application time on seed cotton yield in Pakistan. $\mathrm{K}_{0}=$ No-K; $\mathrm{K}_{1}=100 \mathrm{~kg} \mathrm{~K}_{2} \mathrm{O}$ ha ${ }^{-1}$ single basal application; $\mathrm{K}_{1 \mathrm{~s}}=100 \mathrm{~kg} \mathrm{~K}_{2} \mathrm{O}$ ha $^{-1}$ (50\% at sowing and $50 \%$ at 45 days after sowing; $\mathrm{K}_{2}=200 \mathrm{~kg} \mathrm{~K}_{2} \mathrm{O}$ ha ${ }^{-1}$ basal application; $\mathrm{K}_{2 \mathrm{~s}}=200 \mathrm{~kg}$ $\mathrm{K}_{2} \mathrm{O} \mathrm{ha}^{-1}$ (25\% at sowing; $25 \%$ at 30 days after sowing; $25 \%$ at 45 days after sowing; and $25 \%$ at 60 days after sowing). Columns with the same letters do not significantly differ ( $L S D=0.05)$. Adapted from Muhammad et al. (2016)

equal splits produced $3.6 \%$ and $7 \%$ higher seed-cotton yield, respectively, compared to a single $\mathrm{K}$ fertilizer dose applied at sowing (Muhammad et al. 2016) (Fig. 13.4). The $\mathrm{K}$ requirement of cotton can be met by pre-plant soil application and/or mid-season side-dressing of $\mathrm{K}$.

Foliar K applications offer the opportunity to correct the deficiency, especially at later growth stages when soil application may not be effective. The K concentration in leaf petioles of cotton improved significantly at 70, 90, and 110 days after sowing when $2 \% \mathrm{KNO}_{3}$ sprays were made at critical crop demand stages (Jyothi et al. 2016, Table 13.4). Studies conducted in Tennessee, USA, reported increased cotton yield following foliar $\mathrm{K}$ fertilization when applied in a no-till system (Abaye 2009). Three to four foliar applications of $\mathrm{K}\left(2.0 \% \mathrm{w} / \mathrm{v} \mathrm{K}_{2} \mathrm{SO}_{4}\right)$ are recommended during peak boll development at 7-10-day intervals, beginning about 2 weeks after flower initiation.

In sugarcane-based cropping systems of northwest India, application of $120 \mathrm{~kg}$ $\mathrm{K}_{2} \mathrm{O} \mathrm{ha}^{-1}$ to both the initially planted crop as well the succeeding ratoon crop had the 


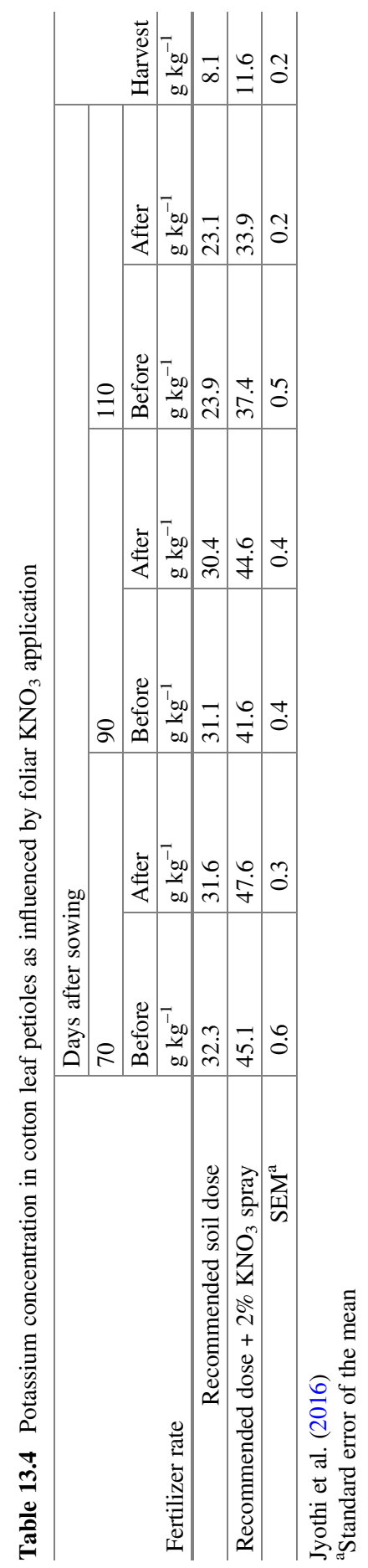


Table 13.5 Effect of split application of $120 \mathrm{~kg} \mathrm{~K} \mathrm{ha}^{-1}$ on yield and potassium recovery efficiency $\left(\mathrm{RE}_{\mathrm{K}}\right)$ of sugarcane and wheat under sugarcane-ratoon-wheat system

\begin{tabular}{l|l|l|l|l|l|l}
\hline \multirow{2}{*}{$\begin{array}{l}\text { Potassium rate and } \\
\text { time of application }\end{array}$} & $\begin{array}{l}\text { Yield } \\
\text { Sugarcane } \\
\text { plant crop }\end{array}$ & $\begin{array}{l}\text { Sugarcane } \\
\text { ratoon }\end{array}$ & Wheat & $\begin{array}{l}\text { Sugarcane } \\
\text { plant crop }\end{array}$ & $\begin{array}{l}\text { Sugarcane } \\
\text { ratoon } \\
\text { crop }\end{array}$ & Wheat \\
\hline $\mathrm{kg} \mathrm{K}_{2} \mathrm{O} \mathrm{ha}^{-1}$ & $\mathrm{Mg} \mathrm{ha}{ }^{-1}$ & & $\mathrm{~kg} \mathrm{~K}(\mathrm{~kg} \mathrm{~K})^{-1}$ & - & - \\
\hline 0 & 49.4 & 61.7 & 3.7 & - & - & 0.514 \\
\hline $\begin{array}{l}120 \text { to sugarcane plant } \\
\text { crop as basal }\end{array}$ & 56.4 & 68.2 & 3.5 & 0.513 & & 0.521 \\
\hline $\begin{array}{l}60 \text { to plant crop as } \\
\text { basal and } 60 \text { to plant } \\
\text { crop at grand growth } \\
\text { phase }\end{array}$ & 67.4 & 80.6 & 3.9 & 0.678 & - & \\
\hline $\begin{array}{l}60 \text { to plant crop as } \\
\text { basal and } 60 \text { to ratoon } \\
\text { as basal }\end{array}$ & 55.7 & 81.3 & 4.1 & 0.546 & 0.597 & 0.589 \\
\hline $\begin{array}{l}60 \text { to ratoon as basal } \\
\text { and } 60 \text { to ratoon at } \\
\text { grand growth phase }\end{array}$ & 68.6 & 92.3 & 4.8 & 0.668 & 0.736 & 0.602 \\
\hline
\end{tabular}

Singh et al. (2008)

highest biomass productivity, compared with $\mathrm{K}$ application to planted crop only (Table 13.5). Additionally, $\mathrm{K}$ application in two splits (basal and at grand growth stage) resulted in higher yield, $\mathrm{K}$ use efficiency, and juice quality (Singh et al. 2008). In Florida, the recommended application rate has been as high as $450 \mathrm{~kg} \mathrm{~K}_{2} \mathrm{O} \mathrm{ha}^{-1}$ for the first growth cycle (ratoon), then reduced to $270 \mathrm{~kg} \mathrm{~K}_{2} \mathrm{O} \mathrm{ha}{ }^{-1}$ for the second and third ratoons (Rice et al. 2006). Hunsigi (2011) suggested application of up to $350 \mathrm{~kg} \mathrm{~K}_{2} \mathrm{O} \mathrm{ha}^{-1}$ and $117 \mathrm{~kg} \mathrm{~K}_{2} \mathrm{O} \mathrm{ha}{ }^{-1}$ for the first and second ratoons of sugarcane, respectively. Singh et al. (2008) settled on a standard rate of $150 \mathrm{~kg} \mathrm{~K}_{2} \mathrm{O} \mathrm{ha}^{-1}$ in their experimental studies in India, while De Oliveira et al. (2016) concluded that $98 \mathrm{~kg}$ $\mathrm{K}_{2} \mathrm{O} \mathrm{ha}^{-1}$ would be sufficient to obtain a stable sugarcane yield of $80 \mathrm{tha}^{-1}$.

\subsection{Fertigation for Synchronized Potassium Supply}

Fertigation provides an excellent opportunity to optimize nutrient application to crops, with co-benefits of greater nutrient and water use efficiencies and economic return compared with soil application. The nutrient application rate and time can be more precisely regulated in fertigation to match crop demand at different growth stages. Another advantage of applying $\mathrm{K}$ through fertigation is that it minimizes the risk applied $\mathrm{K}$ being removed from the solution through clay fixation. Synchronized application of $\mathrm{K}$ with plant demand and applying the fertilizer $\mathrm{K}$ precisely in the root zone reduces the residence time of the $\mathrm{K}$ fertilizer in the soil, thus minimizing the contact of the $\mathrm{K}$ ions with the soil volume. However, when plant $\mathrm{K}$ demands are 
Table 13.6 Potassium recommendation $\left(\mathrm{kg} \mathrm{K}_{2} \mathrm{O} \mathrm{ha}{ }^{-1}\right)$ at different stages of crops under microirrigation-based fertigation

\begin{tabular}{|c|c|c|c|c|c|}
\hline & $\begin{array}{l}\text { Transplanting } \\
\text { to } 6 \text { leaf stage }\end{array}$ & $\begin{array}{l}6 \text { leaf to fruit } \\
\text { setting stage }\end{array}$ & $\begin{array}{l}\text { Fruit setting stage to } \\
\text { fruit development } \\
\text { stage }\end{array}$ & $\begin{array}{l}\text { Fruit setting } \\
\text { stage to ripening } \\
\text { stage }\end{array}$ & Total \\
\hline Crops $^{\mathrm{a}}$ & $\mathrm{kg} \mathrm{K}_{2} \mathrm{O} \mathrm{ha}{ }^{-1}$ & $\mathrm{~kg} \mathrm{~K}_{2} \mathrm{O} \mathrm{ha}^{-1}$ & $\mathrm{~kg} \mathrm{~K}_{2} \mathrm{O} \mathrm{ha}^{-1}$ & $\mathrm{~kg} \mathrm{~K}_{2} \mathrm{O} \mathrm{ha}^{-1}$ & $\begin{array}{l}\mathrm{kg} \\
\mathrm{K}_{2} \mathrm{O} \\
\mathrm{ha}^{-1}\end{array}$ \\
\hline Potato & 16 & 58 & 196 & - & 270 \\
\hline Tomato & 58 & 35 & 45 & 172 & 310 \\
\hline Bell pepper & 58 & 35 & 45 & 172 & 310 \\
\hline Onion & 60 & 32 & 171 & 32 & 295 \\
\hline $\begin{array}{l}\text { Red } \\
\text { cabbage }\end{array}$ & 32 & 35 & 173 & - & 240 \\
\hline Carrot & 120 & 171 & 171 & - & 400 \\
\hline Lettuce & 122 & 35 & - & - & 90 \\
\hline Cucumber & 121 & 35 & 35 & - & 125 \\
\hline Watermelon & 10 & 25 & 75 & - & 120 \\
\hline
\end{tabular}

Unpublished data from authors

${ }^{a}$ Bell pepper (Capsicum annuum L.); carrot (Daucus carota subsp. sativus (Hoffm.) Arcang.); cucumber (Cucumis sativus L.); lettuce (Lactuca sativa L.); onion (Allium cepa L.); potato (Solanum tuberosum L.); red cabbage (Brassica oleracea L.); tomato (Solanum lycopersicum L.); watermelon (Citrullus lanatus (Thunb.) Matsum. \& Nakai)

high, supplying the entire plant $\mathrm{K}$ requirement via fertigation will require a continuous nutrient supply throughout the growing season to ensure optimum yield and quality (Kafkafi and Tarchitzky 2011). Gupta et al. (2015) suggested drip irrigation at $80 \%$ evapotranspiration (ET) and fertigation with $60 \%$ of the recommended NPK for improving yield and water and nutrient use efficiencies in tomato. Fertilizers with high solubility are used for fertigation. Several of the common K fertilizers such as potassium chloride ( $\mathrm{KCl}$; MOP), potassium sulfate (SOP), monopotassium phosphate (MKP), and potassium nitrate $\left(\mathrm{KNO}_{3}\right)$ are excellent sources for fertigation. Potassium recommendations for different crops grown under micro-irrigation-based fertigation are given in Table 13.6.

\subsection{Use of Decision Support Tools}

The fertilizer decision support tool, Nutrient Expert ${ }^{\circledR}$, developed by the International Plant Nutrition Institute (IPNI) along with several national and international partners, has been successfully used to estimate site-specific $\mathrm{K}$ recommendation for major cereal crops and cropping systems. On-farm studies in different agroecologies in India showed that the tool-based $\mathrm{K}$ recommendations for rice-wheat, rice-rice, rice-maize, and maize-wheat systems, based on the nutrient demand of a 
Table 13.7 Effect of Nutrient Expert ${ }^{\circledR}$ (NE)-based $\mathrm{K}$ inputs on grain yield and $\mathrm{K}$ uptake under cereal-based cropping systems

\begin{tabular}{|c|c|c|c|c|c|c|c|c|c|}
\hline \multirow{3}{*}{$\begin{array}{l}\text { Cropping } \\
\text { system }\end{array}$} & \multirow[b]{3}{*}{ Crop $^{\mathrm{a}}$} & \multicolumn{3}{|c|}{$\mathrm{K}$ use } & \multicolumn{3}{|c|}{ Grain yield } & \multicolumn{2}{|c|}{ K uptake } \\
\hline & & FFP & $\mathrm{NE}$ & $\begin{array}{l}\text { Diff. } \\
\text { (NE-FFP) }\end{array}$ & FFP & $\mathrm{NE}$ & $\begin{array}{l}\text { Yield gain over } \\
\text { FFP }\end{array}$ & FFP & $\mathrm{NE}$ \\
\hline & & \multicolumn{3}{|c|}{$\mathrm{kg} \mathrm{K}_{2} \mathrm{O} \mathrm{ha}^{-1}$} & \multicolumn{2}{|c|}{$\mathrm{Mg} \mathrm{ha}^{-1}$} & $\%$ & \multicolumn{2}{|c|}{$\mathrm{kg} \mathrm{K} \mathrm{ha}^{-1}$} \\
\hline \multirow[t]{2}{*}{ Rice-wheat } & Rice & 40 & 67 & +27 & 5.1 & 5.83 & 14 & 104 & 139 \\
\hline & Wheat & 0 & 64 & +64 & 3.66 & 4.18 & 14 & 89 & 101 \\
\hline \multirow[t]{2}{*}{ Rice-rice } & $\begin{array}{l}\text { Rice } \\
(\mathrm{m})\end{array}$ & 60 & 61 & +1 & 4.28 & 4.98 & 16 & 81 & 106 \\
\hline & $\begin{array}{l}\text { Rice } \\
\text { (w) }\end{array}$ & 52 & 46 & +6 & 4.67 & 5.38 & 15 & 91 & 124 \\
\hline \multirow[t]{2}{*}{ Maize-wheat } & Maize & 19 & 44 & +25 & 2.1 & 3.5 & 67 & 57 & 78 \\
\hline & Wheat & 0 & 63 & +63 & 2.21 & 3.51 & 59 & 52 & 81 \\
\hline
\end{tabular}

FFP, farmer fertilizer practice; NE, Nutrient Expert ${ }^{\circledR}$ recommendations

Unpublished data from authors

${ }^{\mathrm{a}}$ Maize (Zea mays L.); rice (Oryza sativa $\mathrm{L}$.); rice (m), rice grown during the monsoon season; rice (w), winter rice; wheat (Triticum aestivum L.)

Table 13.8 A comparison of the effects of a single basal $\mathrm{K}$ application (State recommendation) with split $\mathrm{K}$ applications (recommended by Nutrient Exper $^{(\mathbb{R}}$ ) for two different maize yield targets on: grain yield, $\mathrm{K}$ partial factor productivity $\left(\mathrm{PFP}_{\mathrm{K}}\right)$, and grain produced per rupee invested

\begin{tabular}{|c|c|c|c|c|c|c|}
\hline \multirow[b]{3}{*}{$\mathrm{K}$ recommendation } & \multicolumn{3}{|c|}{ Fertilizer K rate } & \multirow[b]{2}{*}{$\begin{array}{l}\text { Grain } \\
\text { yield }\end{array}$} & \multirow[b]{2}{*}{$\mathrm{PFP}_{\mathrm{K}}$} & \multirow[b]{2}{*}{$\begin{array}{l}\text { Grain produced } \\
\text { per rupee invested }\end{array}$} \\
\hline & Basal & $\begin{array}{l}40 \text { days } \\
\text { after } \\
\text { sowing }\end{array}$ & Total & & & \\
\hline & \multicolumn{3}{|c|}{$\mathrm{kg} \mathrm{K} \mathrm{ha}^{-1}$} & $\begin{array}{l}\mathrm{Mg} \\
\mathrm{ha}^{-1}\end{array}$ & $\begin{array}{l}\text { kg grain } \\
(\mathrm{kg} \mathrm{K})^{-1}\end{array}$ & $\begin{array}{l}\text { kg grain (rupee } \\
\text { invested) }^{-1}\end{array}$ \\
\hline State & 62 & - & 62 & 4.10 & 66.1 & 1.68 \\
\hline $\begin{array}{l}\mathrm{NE} \text { using a } 6 \mathrm{Mg} \mathrm{ha}^{-1} \\
\text { yield target }\end{array}$ & 38 & 25 & 63 & 5.59 & 88.7 & 2.26 \\
\hline $\begin{array}{l}\mathrm{NE} \text { using a } 7 \mathrm{Mg} \mathrm{ha}^{-1} \\
\text { yield target }\end{array}$ & 40 & 27 & 67 & 6.19 & 92.4 & 2.35 \\
\hline
\end{tabular}

NE, Nutrient Expert; State, state recommendation

Unpublished data from authors

high-yielding cereal crop and the soil nutrient supplying capacity, increased crop yield and K uptake over the existing farmers' fertilizer practices (Table 13.7).

The Nutrient Expert considers the yield targets along with soil indigenous nutrient supplying capacity to determine the $\mathrm{K}$ application rate. It also recommends the time of application to meet $\mathrm{K}$ demand at the right physiological growth stages of the crop. Such synchronized K supply to the crops led to higher K uptake and K use efficiencies. A recent study conducted in IGP indicated that the $\mathrm{K}$ recommendations from the Nutrient Expert varied with changing yield targets. The yield gain and efficiency parameters (partial factor productivity and economic KUE) were more with highest yield targets $\left(7 \mathrm{t} \mathrm{ha}^{-1}\right)$ (Table 13.8). 


\subsection{Future Thrusts}

The timing of $\mathrm{K}$ fertilizer application to crops is site- and crop-specific. Typically, $\mathrm{K}$ fertilizers are applied at the time of land preparation as $\mathrm{K}$ is relatively immobile in the soil. It presupposes that the basally applied $\mathrm{K}$ will be held by the soil matrix and will continue to meet the $\mathrm{K}$ demand throughout the crop growth period. However, the variability in soil types in terms of cation-holding capacities and texture may change the mobility of $\mathrm{K}$ ions within the soil. For example, a highly weathered red and lateritic soil would most likely not have enough K-holding capacity, and the fast percolation of water in such soils can facilitate the loss of $\mathrm{K}$ from the root zone. Under such situations, a split application of $\mathrm{K}$ is appropriate to ensure an adequate supply at the right physiological stages. Research is necessary to outline the best time of application of $\mathrm{K}$ fertilizers in the crop-soil context that integrates the soil characteristics, duration of the crop-growing period, physiological stages of high $\mathrm{K}$ demand, and the influence of seasonal differences on physiological growth stages.

It is well recognized that $\mathrm{K}$ plays a significant role in the transport of photosynthates to economic plant parts during the reproductive phase. So splitting K applications to match the demand at the initial growth stage and at the reproductive phase can ensure better productivity and KUE. Evidence from recent research in rice nutrition showed significant gains when the basal $\mathrm{K}$ application is skipped, and $\mathrm{K}$ is applied at the time of maximum tillering and panicle initiation. This particularly makes sense for puddled transplanted rice, where submergence releases soil matrixheld $\mathrm{K}$ into a solution that can meet the $\mathrm{K}$ demand of early growth, and the external $\mathrm{K}$ application could be done at the reproductive stage. More research is needed, not only for rice but also for other crops, to outline suitable fertilizer-splitting strategies for $\mathrm{K}$, and the proportion of $\mathrm{K}$ fertilizer to be applied in each split.

Developing a better fertilizer-splitting strategy for crops has another practical advantage, particularly in areas where access to $\mathrm{K}$ fertilizers is limited. Many farmers often skip K application entirely when they cannot apply fertilizer $\mathrm{K}$ at the time of land preparation due to the unavailability of $\mathrm{K}$ fertilizer in the market. A better understanding of the benefits of late-applied $\mathrm{K}$ on yield, quality, and nutrient use efficiencies will provide farmers incentive to apply $\mathrm{K}$ at later growth stages for better return on investment. Another important area of research is optimizing K application in cropping systems where multiple crops are grown in sequence. Significant gains, both in crop yield and KUE could be achieved by developing application strategies that are based on the $\mathrm{K}$ requirement of the component crops grown in sequence and the crop growing ecology. For example, in a rice (anaerobic)-maize (aerobic) cropping system, better utilization efficiency could likely be achieved by applying the lower proportion of the total system $\mathrm{K}$ requirement to rice and the rest higher proportion to maize. Similar research on intercropping is necessary wherein very little guidance is available regarding $\mathrm{K}$ application to match crop demand.

Crop establishment under zero-tillage and the return of crop residues also have a profound impact on $\mathrm{K}$ dynamics in soils that influence the optimal timing and rate of $\mathrm{K}$ fertilizer application. However, in most cases, protocols of $\mathrm{K}$ fertilizer application 
in conventional tillage systems are replicated in no-till systems, with limited understanding of $\mathrm{K}$ release from crop residues and their utilization by crops or loss from the system. Significant knowledge gaps are also evident in farming systems where crops receive nutrients through fertigation or through foliar fertilization. What should be the rates or timing of $\mathrm{K}$ application in such systems where expected nutrient use efficiencies are significantly higher than soil-applied nutrients need further research to accrue full benefits of investments made on deploying foliar or fertigation systems.

In general, the right time of $\mathrm{K}$ fertilizer application rates for major crops like rice, wheat, maize, plantation, and cash crops are well defined. But much remains to be done to understand how to synchronize $\mathrm{K}$ application with plant demand for cropping systems, intercrops, and minor crops that fit into specific cropping systems where significant variabilities challenge timing decisions.

\subsection{Conclusion}

Potassium is a major nutrient required for many physiological functions in the plants. Adequate $\mathrm{K}$ application based on specific crop requirements (quantity) and synchronizing it with the high $\mathrm{K}$ demand stages of the crops (timing) are essential for optimum crop growth and productivity. Matching $\mathrm{K}$ application with the crop demand also ensures the effective utilization of applied $\mathrm{K}$ nutrients by the plants leading to higher KUE and return on investment. Despite high K requirements, its applications in crops are limited and a negative partial balance of $\mathrm{K}$ is common in most of the intensively cultivated regions of the world. This chapter, besides summarizing the benefits of adequate and synchronized $\mathrm{K}$ input on yield, produce quality, and KUE, also highlights significant knowledge gaps in defining the most appropriate time of $\mathrm{K}$ fertilizer application in specific climate-soil-crop combinations. Intensive agriculture systems around the world will benefit by bridging these knowledge gaps to produce more from less lands with the efficient use of $\mathrm{K}$ fertilizers. The foregoing discussions established the significance of judicious $\mathrm{K}$ input for enhancing productivity and use efficiency of $\mathrm{K}$ and other nutrients in cropping systems. The myths of adequacy of soil $\mathrm{K}$ in the alluvial soils, such as in the Indo-Gangetic Plain, have been negated by profuse crop responses to $\mathrm{K}$ fertilization in these regions. Studies on synchronizing K supplies with crop demand are, however, scarce despite their significance in improving $\mathrm{K}$ fertilizer recommendations. Future investigations should involve crop- and soil-specific comparison of split application vis-à-vis conventional one-time application with respect to crop yields, use efficiency, native $\mathrm{K}$ mining, and losses from root zone. 


\section{References}

Abaye AO (2009) Potassium fertilization of cotton. Virginia Cooperative Extension, 418-025. Available from: https://www.pubs.ext.vt.edu/418/418-025/418-025.html. Accessed May 212020

Acharya CL, Kapur OC, Dixit SP (1998) Moisture conservation for rainfed wheat production with alternative mulches and conservation tillage in the hills of northwest India. Soil Till Res 46:153-163. https://doi.org/10.1016/S0167-1987(98)00030-0

Askegaard M, Eriksen J, Johnston AE (2004) Sustainable management of potassium. In: Schjønning P, Elmholt S, Christensen BT (eds) Managing soil quality-challenges in modern agriculture. CAB, Wallingford, UK, pp 85-102

Bajwa MI (1994) Soil potassium status, potash fertilizer usage and recommendations in Pakistan. Potash Review, No. 3, International Potash Institute, Berne, Switzerland

Balota EL, Colozzi A, Andrade DS, Dick RP (2004) Long-term tillage and crop rotation effects on microbial biomass and $\mathrm{C}$ and $\mathrm{N}$ mineralization in a Brazilian Oxisol. Soil Till Res 77:137-145. https://doi.org/10.1016/j.still.2003.12.003

Bijay-Singh, Yadviner-Singh, Imas P, Xie JC (2003) Potassium nutrition of the rice-wheat cropping system. Adv Agron 81:203-259. https://doi.org/10.1016/S0065-2113(03)81005-2

Chakraborty D, Shantha N, Aggarwal P, Gupta VK, Tomar RK, Garg RN, Sahoo RN, Sarkar A, Chopra UK, Sundara Sarma KS, Kalra N (2008) Effect of mulching on soil and plant water status and the growth and yield of wheat (Triticum aestivum L.) in a semi-arid environment. Agric Water Manag 95:1323-1334. https://doi.org/10.1016/j.agwat.2008.06.001

Cuin TA, Miller AJ, Laurie SA, Leigh RA (2003) Potassium activities in cell compartments of saltgrown barley leaves. J Exp Bot 54:657-661. https://doi.org/10.1093/jxb/erg072

Damon PM, Osborne LD, Rengel Z (2007) Canola genotypes differ in potassium efficiency during vegetative growth. Euphytica 156:387-397. https://doi.org/10.1007/s10681-007-9388-4

De Datta SK, Mikkelsen DS (1985) Potassium nutrition of rice. In: Munson RD (ed) Potassium in agriculture. ASA/CSSA/SSSA, Madison, WI, pp 665-699. https://doi.org/10.2134/1985.potas sium.c30

De Oliveira RI, De Medeiros MRFA, Freire CS, Freire FJ, Neto DES, De Oliveira ECA (2016) Nutrient partitioning and nutritional requirement in sugarcane. Aust J Crop Sci 10:69-75

Dobermann A (2007) Nutrient use efficiency—measurement and management. In: Fertilizer best management practices: general principles, strategy for their adoption and voluntary initiatives vs regulations. Proceedings of IFA international workshop on fertilizer best management practices, 7-9 Mar 2007, Brussels, Belgium. International Fertilizer Industry Association, Paris, France, pp $1-28$

Dobermann A, Oberthür T (1997) Fuzzy mapping of soil fertility-a case study on irrigated rice land in the Philippines. Geoderma 77:317-339. https://doi.org/10.1016/S0016-7061(97) 00028-1

Dobermann A, Cassman KG, Mamaril CP, Sheehy JE (1998) Management of phosphorus, potassium, and sulfur in intensive, irrigated lowland rice. Field Crops Res 56:113-138. https://doi. org/10.1016/S0378-4290(97)00124-X

Dunlop J, Tomkins B (1976) Genotypes differences in potassium translocation in rye-grass. In: Wardlaw IF, Passioura JB (eds) Transport and transfer process in plants. Academic Press, New York, pp 145-152. https://doi.org/10.1016/B978-0-12-734850-6.50018-6

Dwivedi BS, Meena MC (2015) Soil testing service—retrospect and prospects. Ind J Fertil 11 (10):110-122

Dwivedi BS, Shukla AK, Singh VK, Yadav RL (2001) Results of participatory diagnosis of constraints and opportunities based trials from the state of Uttar Pradesh. In: Rao S, Srivastava $S$ (eds) Development of farmers' resource-based integrated plant nutrient supply systems: experience of a FAO-ICARIFFCO collaborative project and AICRP on soil test crop response correlation. Indian Institute of Soil Science, Bhopal, India, pp 50-75 
Dwivedi BS, Singh VK, Shekhawat K, Meena MC, Dey A (2017) Enhancing use efficiency of phosphorus and potassium under different cropping systems of India. Ind J Fertil 13(8):20-41

Fixen P, Brentrup F, Bruulsema T, Garcia F, Norton R, Zingore S (2015) Nutrient/fertilizer use efficiency: measurement, current situation and trends. In: Drechsel P, Heffer P, Magen H, Mikkelsen R, Wichelns D (eds) Managing water and fertilizer for sustainable agricultural intensification. IFA, IWMI, IPNI, IPI, Paris, France, pp 8-38. https://pdfs.semanticscholar. org/4efc/c3c517d07573dfcbecb7b6ca98874879dba6.pdf. Accessed May 212020

Franzluebbers AJ, Hons FM (1996) Soil-profile distribution of primary and secondary plant available nutrients under conventional and no tillage. Soil Till Res 39:229-239. https://doi. org/10.1016/S0167-1987(96)01056-2

Govaerts B, Sayre KD, Goudeseune B, De Corte P, Lichter K, Dendooven L, Deckers J (2009) Conservation agriculture as a sustainable option for the central Mexican highlands. Soil Till Res 103:222-230. https://doi.org/10.1016/j.still.2008.05.018

Gupta R, Gopal R, Jat ML, Jat RK, Sidhu HS, Minhas PS, Malik RK (2010) Wheat productivity in Indo-Gangetic plains of India: terminal heat effects and mitigation strategies. PACA Newsl 15:1-3. https://www.researchgate.net/publication/279059151_Wheat_productivity_in_IndoGangetic_plains_of_India_during_2010_terminal_heat_effects_and_mitigation_strategies_ PACA_Newslett. Accessed May 212020

Gupta AJ, Chattoo MA, Singh L (2015) Drip irrigation and fertigation technology for improved yield, quality, water and fertilizer use efficiency in hybrid tomato. J AgriSearch 2(2):94-99

Halevy J (1976) Growth rate and nutrient uptake of two cotton cultivars grown under irrigation. Agron J 68:701-705. https://doi.org/10.2134/agronj1976.00021962006800050002x

Hasan R (2002) Potassium status of soils in India. Better Crops Int 16(2):3-5

He P, Jin J, Wang H, Cui R, Li C (2012) Yield responses and potassium use efficiency for winter wheat in North-Central China. Better Crops 96(3):28-30

Hinsinger PH, Jaillard B (2002) Root-induced release of interlayer potassium and vermiculitization of phlogopite as related to potassium depletion in the rhizosphere of ryegrass. J Soil Sci 44:525-534. https://doi.org/10.1111/j.1365-2389.1993.tb00474.x

Howard DD, Gwathmey CO, Roberts RK, Lessman GM (1998) Potassium fertilization of cotton produced on a low K soil with contrasting tillage systems. J Prod Agric 11:74-79. https://doi. org/10.2134/jpa1998.0074

Hunsigi G (2011) Potassium management strategies to realize high yield and quality of sugarcane. Karnataka J Agric Sci 24:45-47

Jin J (2012) Changes in the efficiency of fertilizer use in China. J. Sci Food Agric 92:1006-1009

Jyothi TV, Hebsur NS, Sokolowski E, Bansal SK (2016) Effects of soil and foliar potassium application on cotton yield, nutrient uptake, and soil fertility status. Int Potash Inst e-ifc 46:13-21

Kafkafi U, Tarchitzky J (2011) Fertigation: a tool for efficient fertilizer and water management. International Fertilizer Industry Association, Paris

Kirkby EA, Römheld V (2004) Micronutrients in plant physiology: functions, uptake and mobility. The International Fertiliser Society, York, UK. https://fertiliser-society.org/store/ micronutrients-in-plant-physiology-functions-uptake-and-mobility/. Accessed May 212020

Kolar JS, Grewal HS (1989) Response of rice to potassium. Int Rice Res Newsl 14:33-40

Kushwaha CP, Tripathi SK, Singh KP (2000) Variations in soil microbial biomass and N availability due to residue and tillage management in a dryland rice agroecosystem. Soil Till Res 56:153-166. https://doi.org/10.1016/S0167-1987(00)00135-5

Ladha JK, Dawe D, Pathak H, Padre AT, Yadav RL, Singh B, Singh Y, Singh Y, Singh P, Kundu AL, Sakal R, Ram N, Regmi AP, Gami SK, Bhandari AL, Amin R, Yadav CR, Bhattarai EM, Das S, Aggarwal HP, Gupta RK, Hobbs PR (2003) How extensive are yield declines in longterm rice wheat experiments in Asia? Field Crops Res 81:159-180

Leigh RA (2001) Potassium homeostasis and membrane transport. J Plant Nutr Soil Sci:164193-164198. https://doi.org/10.1002/1522-2624(200104)164:2<193::AIDJPLN193>3.0.CO;2-7 
Leigh RA, Wyn Jones RG (1984) A hypothesis relating critical potassium concentrations for growth to the distribution and functions of this ion in the plant cell. New Phytol 97:1-13. https://doi.org/10.1111/j.1469-8137.1984.tb04103.x

Majumdar K, Sanyal SK (2015) Soil and fertilizer phosphorus and potassium. In: Rattan RK, Katyal JC, Dwivedi BS, Sarkar AK, Bhattacharyya T, Tarafdar JC, Kukal SS (eds) Soil science: an introduction. Indian Society of Soil Science, New Delhi, pp 571-600. ISBN: 81-903797-7-1

McLean EO, Watson ME (1985) Soil measurements of plant available potassium. In: Munson RD (ed) Potassium in agriculture. ASA, CSSA, SSSA, Madison, WI, pp 277-308. https://doi.org/ 10.2134/1985.potassium.c10

Memon AR, Saccomani M, Glass ADM (1985) Efficiency of potassium utilization by barley varieties: The role of subcellular compartmentation. J Exp Bot 36:1860-1876. www.jstor.org/ stable/23691362

Mengel K, Kirkby EA (2001) Principles of plant nutrition, 5th edn. Springer. 849 pp. https://doi. org/10.1007/978-94-010-1009-2

Moody PW, Bell MJ (2006) Availability of soil potassium and diagnostic soil tests. Aust J Soil Res 44:265-275. https://doi.org/10.1071/SR05154

Muhammad DB, Afzal MN, Tariq M, Wakeel A (2016) Impact of potassium fertilization dose, regime, and application methods on cotton development and seed-cotton yield under an arid environment. Int Potash Inst e-ifc 45:3-10

Mullins GL, Burmester CH (1990) Dry matter, nitrogen, phosphorus, and potassium accumulation by four cotton varieties. Agron J 82:729-736. https://doi.org/10.2134/agronj1990. $00021962008200040017 x$

Öborn I, Andrist-Range Y, Askekaard M, Grant CA, Watson CA, Edwards AC (2005) Critical aspects of potassium management in agricultural systems. Soil Use Manag 21:102-112. https:// doi.org/10.1111/j.1475-2743.2005.tb00414.x

Pal Y, Gilkes RJ, Wong MTF (2001a) Mineralogy and potassium release from some Western Australian soils and their size fractions. Aust J Soil Res 39:813-822. https://doi.org/10.1071/ SR00031

Pal Y, Gilkes RJ, Wong MTF (2001b) Soil factors affecting the availability of potassium to plants for Western Australian soils: A glasshouse study. Aust J Soil Res 39:611-625. https://doi.org/ 10.1071/SR00030

Pal Y, Gilkes RJ, Wong MTF (2002) Mineral sources of potassium to plants for seven soils from south-western Australia. Aust J Soil Res 40:1357-1369. https://doi.org/10.1071/SR02014

Pettigrew WT (2008) Potassium influences on yield and quality production for maize, wheat, soybean and cotton. Physiol Plant 133:670-681. https://doi.org/10.1111/j.1399-3054.2008. 01073.x

Regmi AP, Ladha JK, Pasquin E, Pathak H, Hobbs PR, Shrestha LL, Gharti DB, Duveiller E (2002) The role of potassium in sustaining yields in a long-term rice-wheat experiment in the IndoGangetic Plains of Nepal. Biol Fert Soils 36:240-247. https://doi.org/10.1007/s00374-0020525-x

Rengel Z, Damon PM (2008) Crops and genotypes differ in efficiency of potassium uptake and use. Physiol Plant 133:624-636. https://doi.org/10.1111/j.1399-3054.2008.01079.x

Rice RW, Gilbert RA, McCray JM (2006) Nutritional requirements for Florida sugarcane. In: Gilbert, RA, Rice RW, McCray JM (eds) Sugarcane handbook. Univ Florida Extension Pub \#SS-AGR-228. https://edis.ifas.ufl.edu/sc028. Accessed May 212020

Singh VK, Tiwari R, Gill MS, Sharma SK, Tiwari KN, Dwivedi BS, Shukla AK, Mishra PP (2008) Economic viability of site-specific nutrient management in rice-wheat cropping. Better Crops-India 2:16-19

Singh VK, Dwivedi BS, Buresh RJ, Jat ML, Majumdar K, Gangwar B, Govil V, Singh SK (2013) Potassium fertilization in rice-wheat system across Northern India: Crop performance and soil nutrients. Agron J 105:471-481. https://doi.org/10.2134/agronj2012.0226

Singh VK, Dwivedi BS, Tiwari KN, Majumdar K, Rani M, Singh SK, Timsina J (2014) Optimizing nutrient management strategies for rice-wheat system in the Indo-Gangetic Plains of India and 
adjacent region for higher productivity, nutrient use efficiency and profits. Field Crops Res 164:30-44. https://doi.org/10.1016/j.fcr.2014.05.007

Singh VK, Shukla AK, Dwivedi BS, Singh MP, Majumdar K, Kumar V, Mishra R, Rani M, Singh SK (2015a) Site-specific nutrient management under rice-based cropping systems in IndoGangetic Plains: Yield, profit and apparent nutrient balance. Agric Res 4:365-377. https://doi. org/10.1007/s40003-015-0179-1

Singh VK, Shukla AK, Singh MP, Mujumdar K, Mishra RP, Rani M, Singh SK (2015b) Effect of site-specific nutrient management on yield, profit and apparent nutrient balance under pre-dominant cropping systems of Upper Gangetic Plains. Indian J Agric Sci 85:335-343

Singh VK, Dwivedi BS, Yadvinder-Singh SSK, Mishra RP, Shukla AK, Rathore SS, Shekhawat K, Majumdar K, Jat ML (2018) Effect of tillage and crop establishment, residue management and $\mathrm{K}$ fertilization on yield, $\mathrm{K}$ use efficiency and apparent $\mathrm{K}$ balance under rice maize system in north-western India. Field Crops Res 224:1-12. https://doi.org/10.1016/j.fcr.2018.04.012

Smil V (1999) Crop residues: Agriculture's largest harvest: Crop residues incorporate more than half of the world's agricultural phytomass. BioScience 49:299-308. https://doi.org/10.2307/ 1313613

Springob G, Richter J (1998) Measuring interlayer potassium release rates from soil materials. II. A percolation procedure to study the influence of the variable 'solute $\mathrm{K}$ ' in the $<1 \ldots 10 \mu \mathrm{M}$ range. J Plant Nutr Soil Sci 161:323-329. https://doi.org/10.1002/jpln.1998.3581610321

Sri Adiningsih J, Santoso D, Sudjadi M (1991) The status of N, P, K and S of lowland rice soils in Java. In: Blair G, Lefroy RDB (eds) Sulfur fertilizer policy for lowland and upland rice cropping systems in Indonesia. Australian Centre for International Agricultural Research, Melbourne

Steingrobe B, Claassen N (2000) Potassium dynamics in the rhizosphere and K efficiency of crops. J Plant Nutr Soil Sci 163:101-106. https://doi.org/10.1002/(SICI)1522-2624(200002) $163: 1<101::$ AID-JPLN101 >3.0.CO;2-J

Syers JK (2003) Potassium in soils: current concepts. In: Johnston AE (ed) Feed the soil to feed the people :The role of potash in sustainable agriculture. Proceedings of IPI Golden Jubilee Congress 1952-2002, Basel, Switzerland, 8-10 Oct 2002. International Potash Institute, Basel, Switzerland, pp 301-310

Tandon HLS, Sekhon GS (1988) Potassium research and agricultural production in India. Fertilizer Development and Consultation Organisation, New Delhi. ISBN: 10:8185116059

Timsina J, Connor DJ (2001) Productivity and management of rice-wheat cropping systems: Issues and challenges. Field Crops Res 69:93-132. https://doi.org/10.1016/S0378-4290(00)00143-X

Timsina J, Jat ML, Majumdar K (2010) Rice-maize systems of South Asia: Current status, future prospects and research priorities for nutrient management. Plant Soil 335:65-82. https://doi.org/ 10.1007/s11104-010-0418-y

Timsina J, Singh VK, Majumdar K (2013) Potassium management in rice-maize systems in South Asia. J Plant Nutr Soil Sci 176:317-330. https://doi.org/10.1002/jpln.201200253

Tiwari KN (2002) Nutrient management: Issues and strategies. Fert News 47:23-122

Tiwari KN, Dwivedi BS, Subba Rao A (1992) Potassium management in rice-wheat system. In: Pandey RK et al (eds) Rice-wheat cropping system: Proceedings of the rice-wheat workshop, Modipuram, Meerut. Project Directorate for Cropping Systems Research, Modipuram, Meerut, India, pp 93-114

Tiwari KN, Sharma SK, Singh VK., Dwivedi BS, Shukla AK (2006) Site-specific nutrient management for increasing crop productivity in India: Results with rice-wheat and rice-rice system. PDCSR Modipuram and PPIC India Programme, Gurgaon, pp 92

Verhulst N, Govaerts B, Verachtert E, Castellanos-Navarrete A, Mezzalama M, Wall P, Deckers J, Sayre KD (2010) Conservation agriculture, improving soil quality for sustainable production systems? In: Lal R, Stewart BA (eds) Advances in soil science: food security and soil quality. CRC, Boca Raton, FL, pp 137-208, ISBN: 10:143980057X

Wilhelm WW, Johnson JMF, Hatfield JL, Voorhees WB, Linden DR (2004) Crop and soil productivity response to corn residue removal: A review of the literature. Agron J 96:1-17. https://doi.org/10.2134/agronj2004.1000 
Woodend JJ, Glass ADM (1993) Genotype-environment interaction and correlation between vegetative and grain production measures of potassium use-efficiency in wheat (T. aestivum L.) grown under potassium stress. Plant Soil 151:39-44. https://doi.org/10.1007/BF00010784 Yadvinder-Singh, Bijay-Singh, Timsina J (2005) Crop residue management for nutrient cycling and improving soil productivity in rice-based cropping systems in the tropics. Adv Agron 85:269-407. https://doi.org/10.1016/S0065-2113(04)85006-5

Zhang G, Chen J, Tirore EA (1999) Genotypic variation for potassium uptake and utilization efficiency in wheat. Nutr Cycl Agroecosyst 54:41-48. https://doi.org/10.1023/ A: 1009708012381

Open Access This chapter is licensed under the terms of the Creative Commons Attribution 4.0 International License (http://creativecommons.org/licenses/by/4.0/), which permits use, sharing, adaptation, distribution and reproduction in any medium or format, as long as you give appropriate credit to the original author(s) and the source, provide a link to the Creative Commons license and indicate if changes were made.

The images or other third party material in this chapter are included in the chapter's Creative Commons license, unless indicated otherwise in a credit line to the material. If material is not included in the chapter's Creative Commons license and your intended use is not permitted by statutory regulation or exceeds the permitted use, you will need to obtain permission directly from the copyright holder. 